\title{
Stress for Vertebral Bodies and Intervertebral Discs with Respect to Squatting Depth
}

\author{
Hagen Hartmann ${ }^{1, *}$, Klaus Wirth ${ }^{2}$, Christoph Mickel ${ }^{1}$, Michael Keiner ${ }^{3}$, Andre Sander ${ }^{4}$ \\ and Dennis Yaghobi ${ }^{3}$ \\ 1 Department of Human Movement Science and Athletic Training, Institute of Sports Sciences, \\ Johann Wolfgang Goethe-University Frankfurt am Main, Ginnheimer Landstraße 39, \\ 60487 Frankfurt am Main, Germany; c.mickel@sport.uni-frankfurt.de \\ 2 Department of Sport and Exercise Sciences, University of Applied Sciences Wiener Neustadt, \\ Johannes Gutenberg-Straße 3, 2700 Wiener Neustadt, Austria; k.wirth@fhwn.ac.at \\ 3 Swimming Federation of the State Lower Saxony, Ferdinand-Wilhelm-Fricke Weg 10, 30169 Hannover, \\ Germany; michael.keiner@landesschwimmverband-niedersachsen.de (M.K.); \\ dennis.yaghobi@landesschwimmverband-niedersachsen.de (D.Y.) \\ 4 Bobsleight and Luge Federation Germany, An der Schießstätte 6, 83471 Berchtesgaden, Germany; \\ a.sander@bsd-portal.de \\ * Correspondence: hagen-hartmann@online.de; Tel.: +49-614-559-8484
}

Academic Editor: Giuseppe Musumeci

Received: 1 March 2016; Accepted: 9 June 2016; Published: 16 June 2016

\begin{abstract}
For the development of speed strength in professional sports, "specific" strength training in the half or the quarter squat have been recommended. Due to the better lever ratios, higher loads have to be used to induce the necessary training stimuli compared to the deep squat. Therefore, intradiscal pressure and compressive forces on vertebral bodies increase. Calculated compressive forces for the L3/L4 vertebral segment were revealed to be 6-10-fold bodyweight when the half or the quarter squat was performed with 0.8-1.6-fold bodyweight. After 10 weeks of training, physical education students have even been able to lift 3.89-fold bodyweight in the one repetition maximum (1-RM) of the quarter squat. The presented dependence of squatting depth, load and their influence on the spinal column have not been discussed before. A search for relevant scientific literature was conducted using PubMed. Concerns about increased risk of injuries in the deep squat have been disproven by plenty of cross-sectional studies with professional athletes. On the contrary, the comparably supramaximal weight loads in the half and the quarter squat should be regarded as increasing injury risks caused by the higher shear and compressive forces in the vertebral column. Therefore, we come to the conclusion that the half and the quarter squat should not further be recommended.
\end{abstract}

Keywords: squat exercise; intradiscal pressure; intervertebral disc; vertebral column stress

\section{Introduction}

The barbell squat can typically be classified into three fundamental variations, which are the front squat, the high-bar and the low-bar back squat. The comparison of back squats shows that higher loads can be managed the low-bar one because of the larger hip flexion [1]. This is why this variation is used in powerlifting [1]. Further, squatting depth may be varied: for the quarter squat, knees are flexed until knee angles of $110^{\circ}-140^{\circ}[2,3]$ are reached. The half squat is performed with knee angles at $80^{\circ}-100^{\circ}[2,4]$. For the parallel squat, the inguinal fold is moved in a straight horizontal line with the top of the knee musculature, which leads to knee angles between $60^{\circ}$ and $70^{\circ}$ [5]. The turning point of the deep squat is typically at a $40^{\circ}-45^{\circ}[1,2,4,6]$ knee angle. The goal of strength training in sports is either to increase muscle cross-sectional area (CSA) via a hypertrophy-oriented training regimen or to improve intra and inter-muscular coordination via maximal contractions. 
In hypertrophy-oriented training, intensities of 70\%-90\% 1-RM (5-12 RM, 3-6 sets per exercise) [7-9] in a periodized alteration $[7,8,10]$ and, depending on the exercise, with inter-serial rest of 1-3 [7-12] or even $4 \mathrm{~min}$ [11] are recommended for advanced trainees. In a meta-analysis of 2004, Fry [13] stressed the importance of the habitual use of $\geqslant 80 \% 1-\mathrm{RM}$ to produce maximal hypertrophy in trained individuals. Training with maximal contractions is accomplished with the method of maximal-explosive strength actions moving high loads under the avoidance of fatigue effects $(90 \%-100 \%$ 1-RM, 1-3 reps, $3-5$ sets, rest between sets of $\geqslant 5 \mathrm{~min}$ ) [9,14]. Angle-specific strength training is based on the idea of exercising only in the range of motion in which competition exercises actually take place $[3,15]$. Consequently, it has been recommended to improve speed strength performance in track and field disciplines [3] and games $[15,16]$ via "specific" strength training in the half and quarter squat.

Because of the better lever ratios in the half [4] and quarter squat [17], considerably higher loads compared to the deep squat are necessary to induce the required training stimuli in hip and leg extensor muscles. Wirth and Zawieja [18] postulated target values of 1.5-2.0-fold bodyweight for the deep squat in the course of a perennial training structure for athletes. These target values should be seen as a minimum, which is nearly impossible to fall short of if training is performed continuously and seriously. More specific target values are dependent on the kind of sport. For professional soccer players, Hoff and Helgerud [16] recommend a relative strength of 2.75-fold bodyweight in the half back squat.

An increase in load increases compressive forces on vertebral bodies [19] and intervertebral discs [20]. Furthermore, higher loads demand more stabilizing work and therefore higher trunk muscle activity [21-23] to counteract damaging anterior shear forces on intervertebral discs [23]. For the half back squat, Dintiman and Ward [24] have described the following performance standards: $1.5 \times$ bodyweight represents a very poor, $1.8 \times$ bodyweight a poor, $2.1 \times$ bodyweight an average, and $2.7 \times$ bodyweight a good performance level. It has been reported that participants of a rather poor $[17,25]$ to good performance level [26] reached relative loads of 2.2- to 2.7-fold bodyweight in the half squat after only $5-8$ weeks $[25,26]$ and even 3.89 -fold bodyweight in the quarter squat after 10 weeks of training [17]. These associations between load level and squatting depth have not been discussed in reviews that have regarded stresses applied on the vertebral column [27].

The aim of this narrative review is to discuss the stress for vertebral bodies and intervertebral discs with respect to squatting depth based on the literature on the lumbar spinal region. Therefore, published estimates of acting compressive forces on L3/L4 and L5/S1 vertebral segments in the half and quarter squat are used to calculate overload damages and structural adaptations of passive tissues of the vertebral column.

\section{Materials and Methods}

A literature search of PubMed (Available online: http://www.ncbi.nlm.nih.gov/pubmed) was conducted including all relevant publications using the following search terms: weightlifting spine, squat spine, weightlifting bone mineral density, in vivo measurements of intradiscal pressure, weightlifting injuries, resistance training injury, dynamic loading cartilage explants and dynamic loading cartilage cells.

\section{Results}

Two publications were found that had calculated compressive forces acting on vertebral segments L3/L4 [19] and L5/S1 [28] while squatting. In three publications, loads normalized by bodyweight for different squatting variations after $5-10$ weeks of training were reported $[17,25,26]$. Four cross-sectional studies could be found that reported data on the extent and incidence of abnormalities of the vertebral column in weightlifters compared to controls and athletes of different sports [29-32]. Another four publications used three-dimensional movement analysis techniques to investigate the movements of the lumbar spinal region during squats [33-36]. 
Maximal axial compressive strength of lumbar vertebrae and segments have been presented in five studies [37-41]. The reported values are shown in Tables 1 and 2. Maximal axial compressive force is the amount of force (Newton) applied on a vertebral body or a vertebral segment that leads to failure. A vertebral segment is defined as an intervertebral disc with its two vertebral bodies. If the applied stress is a combination of high axial compressive and shear forces in a ventrally-flexed position, the intervertebral disc prolapses [42]. However, if axial compressive force represents the applied stress alone, vertebral bodies are the weakest link, and fractures occur $[37,38,40]$. Under these circumstances, intervertebral discs can withstand higher forces compared to vertebral bodies.

Table 1. Maximal compressive strength of the L5 vertebral body and the L5/S1 vertebral segments (average values).

\begin{tabular}{cccc}
\hline Author & $n$ & Structure & Compressive Strength (N) \\
\hline \multirow{2}{*}{ Jäger and Luttmann [40] } & 17 & L5 & 5000 \\
& 8 & L5/S1-disc & 8000 \\
\hline
\end{tabular}

Axial rotational movements in vertebral segments are primarily restricted through fibers of the annulus pulposus [43]. For each rotational direction, only $50 \%$ of all fibers are useful as only those bent in the direction of torque [44]. If synchronously, a ventral flexion is induced, only those $50 \%$ of already bent fibers are stressed [44]. Therefore, a combination of axial compression and torsion in a ventrally-flexed position can only rely on $50 \%$ of the mechanically-induced stability of the vertebral segment [44], which leads to an increased risk for a discus prolapse [45]. An increased potential for damage can already be expected with shear forces of $150 \mathrm{~N} \mathrm{[46]} \mathrm{and} \mathrm{axial} \mathrm{rotation} \mathrm{torque} \mathrm{of} 20 \mathrm{Nm}$ [46].

The average age and sex of specimen have not been reported in detail in the publication of Jäger and Luttmann [40]. The spinal segments had been part of a large number of specimens $(n=441)$ with an age range from $10-90$ years.

To our knowledge, the experimentally-determined maximum for tolerated compressive forces of the $\mathrm{L} 5$ vertebral body is $15,559 \mathrm{~N}$ (see Table 2).

Table 2. Maximal compressive strength of lumbar vertebral bodies and segments.

\begin{tabular}{|c|c|c|c|c|}
\hline Author & Structure & Compressive Strength (N) & Age (Years) & Sex \\
\hline \multirow{2}{*}{ Hutton et al. [39] } & L3 & 12,931 & 46 & male \\
\hline & L5 & 15,559 & 21 & male \\
\hline Porter et al. [41] & L2/L3 & 13,954 & 25 & male \\
\hline \multirow{3}{*}{ Brinckmann et al. [37] } & $\mathrm{L} 3 / \mathrm{L} 4$ & 6200 & 22 & female \\
\hline & $\mathrm{L} 3 / \mathrm{L} 4$ & 8200 & 39 & male \\
\hline & L4/L5 & 8800 & 22 & male \\
\hline Hutton and Adams [38] & L5/S1 & 12,740 & 22 & male \\
\hline
\end{tabular}

In the case of the displayed maximal compressive strength, vertebral bodies were limiting the measures of Brinckmann et al. [37] and Hutton and Adams [38], while Porter et al. [41] reported failure of the intervertebral discs.

\section{Discussion}

\subsection{Comparison of the Calculated Compressive Forces in the Half and Quarter Squat with} Experimentally-Determined Strength Values of Vertebral Bodies and Segments

To the best of the authors' knowledge, there are no calculations about the compressive forces of the lumbar spine between different squatting depths with maximal loads. These estimates are therefore extrapolated from the existing literature. Cappozzo et al. [19] calculated compressive forces on the L3/L4 segment for four subjects, who performed squats with turning points at a $112^{\circ}$ down to 
an $87^{\circ}$ knee angle. Weights of between 0.8 - and 1.6-fold bodyweight resulted in compressive forces of 6-10-fold bodyweight at the turning point of the squat (3100-7340 N). With increasing loads, these authors calculated a raise in compressive forces acting on the vertebral bodies [19] that led to increases of intradiscal pressure [20]. For soccer players performing the half back squat for a period of eight weeks, Helgerud et al. [25] have presented significant increases in 1-RM half squat $(49.2 \%, p \leqslant 0.001)$ with improvements from 1.5-fold bodyweight $(115.7 \pm 23.1 \mathrm{~kg})$ to 2.2 -fold bodyweight $(176.4 \pm 18.2 \mathrm{~kg})$. Cormie et al. [47] have reported that untrained male subjects were able to perform 1-RM in the half squat with 1.4-fold bodyweight without familiarization sessions. Rønnestad [26] had the ability to perform a 1-RM in the half squat with 2.2-fold bodyweight $(150.0 \pm 15.3 \mathrm{~kg})$ as inclusion criteria for his study. However, his participants (recreational sportsmen) showed significant gains of $24.2 \%(p \leqslant 0.01)$ to $186.4 \pm 21.9 \mathrm{~kg}$ in five weeks of training, which is an increase to 2.7 -fold bodyweight. Physical education students exercising the quarter squat to a $120^{\circ}$ knee angle for a period of 10 weeks increased their performance on average from 2.87 - (220.00 $\pm 42.16 \mathrm{~kg})$ to 3.89 -fold bodyweight $(297.89 \pm 41.58 \mathrm{~kg})$ $(37.5 \%, p \leqslant 0.05)$ [17]. Thus, the L3/L4 vertebral segment would have to tolerate compressive forces of more than 17-fold bodyweight in the half [26] and more than 20-fold in the quarter squat [17]. The calculated compressive forces in the half squat after five weeks of training [26] and 10 weeks of training in the quarter squat [17] sum up to $12,359 \mathrm{~N}$ and $14,648 \mathrm{~N}$, respectively, which clearly exceeds the maximally-tolerated values presented in Table 2 . For the deadlift $(212-335 \mathrm{~kg}$, relative strength 3.5 to $4.4 \times$ bodyweight), Granhed et al. [48] have reported even higher axial compressive forces on the L3 vertebral body of 18,800-36,400 $\mathrm{N}$ in six elite powerlifters (bodyweight: $59-93 \mathrm{~kg}$ ). Calculations had been performed via data extracted from movement analysis.

For the loading peaks in the squat, which were analyzed by Cappozzo et al. [19] through ground-reaction forces, they have been far beyond $1 \mathrm{~s}$. For the parallel squat in the study of Lander et al. [28], only relative time scales were used without information about their duration. However, Jäger and Luttmann [49] argued that (calculated) dynamic compressive forces could not be compared to experimentally-determined strength values, since loading peaks of less than a one-second duration may be tolerated by intervertebral discs (in vivo) because of their viscoelastic properties. Therefore, a transfer to in vivo situations should be done restrainedly. Nevertheless, those comparisons raise the question to what extent a performance-oriented strength training including the half and/or quarter squat, which demands comparatively supramaximal loads (with the deep squat), increases the risk of injury for the spine, especially in female athletes. For example, female sport students $(n=23)$, who were mostly inexperienced with strength training, were already able to perform the quarter squat with 2.49-fold bodyweight in the pretest [17]. Due to the significantly smaller female corpus vertebrae [50], their vertebral bodies tolerate significantly less maximal compressive forces than men's [51]. Consequently, if equivalent compressive forces are applied, the axial stress is higher for female vertebral bodies [50]. This should especially be accounted for in the training regimen for young athletes. Furthermore, Zatsiorsky and Kraemer [15] emphasized the importance of stabilization by the trunk muscles (especially erector spinae) when performing squats to counteract potentially damaging anterior shear forces on intervertebral discs resulting from ventral flexion [23]. However, the utilization of comparatively supramaximal loads in the half and quarter squat increases the risk of not being able to stabilize the thoracic and lumbar spinal region. Therefore, the probability of ventral flexion under these circumstances rises, which increases the risk of a disc prolapse [42].

\subsection{Comparison of the Calculated Compressive Forces in the Parallel and Deep Squat with Experimentally-Determined Strength Values of Vertebral Bodies and Segments}

After 10 weeks of training, two groups of physical education students increased their performance in the deep front squat on average from 1.01 -fold $(73.00 \pm 26.48 \mathrm{~kg})$ to 1.26 -fold bodyweight $(90.88 \pm 25.61 \mathrm{~kg})$ and in the deep back squat from 1.12 -fold $(80.25 \pm 30.28 \mathrm{~kg})$ to 1.41 -fold bodyweight $(101.50 \pm 30.00 \mathrm{~kg})(29 \%-30 \%, p \leqslant 0.05)$ [17]. The calculated compressive forces [19] of 3100-7324 $\mathrm{N}$ in the lumbar region (L3/L4 vertebral segment) are, according to Table 2, within the range of tolerance for a 39-year-old male subject. 
According to Lander et al. [28], the calculated axial compressive forces on the L5/S1 vertebral segment were on average $9983 \mathrm{~N}$ at the turning point in the parallel squat with $70 \%-90 \% 1-\mathrm{RM}$ (intensity range of hypertrophy-oriented training [7-9]). Indeed, this calculated value exceeds the average values of $6000-8000 \mathrm{~N}$ presented in Table 1, but it has to be taken into account that those experiments had been performed on very heterogeneous cadavers [40]. The maximally-tolerated compressive force is dependent on sex, age, size of corpus vertebrae $[40,51]$, bone mineral density (BMD) and bone mineral content (BMC) [52]. For example, the maximally-tolerated compressive force in the L5/S1 vertebral segment of a 22-year-old male (ex-vivo) was $12,740 \mathrm{~N}$ and therefore within the calculated range by Lander et al. [28]. Furthermore, the participants $(n=6)$ in the study by Lander et al. [28] were able to perform 1-RM in the parallel squat with 2.38-fold bodyweight, which can only be achieved after several years of intensive strength training.

In comparison, using the half squat as training exercise, similar values have been achieved by soccer players after only eight weeks [25]. It can be expected that compressive stress on the spine applied for several years, as for example in weightlifters [53] and powerlifters [48], leads to structural adaptations of vertebral bodies (L2-L4). Those include increased BMD [53] and BMC [48], which result in higher maximally-tolerated compressive forces, as there is a linear, positive relationship between maximal compressive strength and BMD $(r=0.91 ; p \leqslant 0.00001)$ and BMC $(r=0.84 ; p \leqslant 0.00001)$ (L3) [52]. Further, a cross-sectional study with 25 elite young weightlifters ( $17.4 \pm 1.4$ years) with more than 2.5 years of strength training experience (on average) revealed significantly increased values in BMD of L2-L4 (33\%; $p \leqslant 0.05)$ compared to an age-matched control group $(n=11)$ without group differences for body height and weight. Moreover, their BMD was 13\% $(p \leqslant 0.05)$ higher compared to reference values of 400 males aged between 20 and 39 years [53]. A follow-up investigation showed that another year of weightlifting training increased those values even further [54] (p. 119). Lang et al. [55] and Loehr et al. [56] detected statistically-significant increases in BMD of L1-L2 of between 7\% and 12.3\% after four months of periodized strength training in parallel squats and deadlifts (6-10 RM, [55]; $70 \%-80 \%$ 1-RM [56]). Compared to young women, young men gained statistically significantly more in BMD of the lumbar spine $(2.7 \%-7.7 \%$ vs. $-0.8 \%-1.5 \%)$ after six months of periodized strength training using the same training exercises (67\%-95\% 1-RM). Intragroup changes were not analyzed statistically [57]. The remodelling processes of bones range from 4-6 months [58]. Based on these facts, Chilibeck et al. [59] emphasized the importance of strength training periods that last two to three times longer than this adaptation period to bring about substantial improvements in BMD. Several other studies with male [60-62] and female [63] long time weightlifters have reported significantly increased BMD values in comparison with controls [60-63] and athletes of other sports, as for example cycling, cross-country skiing and orienteering [63].

Concerns about an increased risk of injury performing the deep squat have been disproven by plenty of cross-sectional studies with weightlifters. Neither the extent nor the prevalence of spinal abnormalities was increased compared to other athletes [29,30,32] or controls [30,31]. Compared to controls (non and recreational sportsmen) that were age and gender matched $(n=1347)$, Dalichau and Scheele [31] determined a tendency toward an increasing kyphosis and inclination in the sagittal projection for 29 active weightlifters (C7-S2). These athletes were aged 27.5 years and had a sporting exposure of 10.3 years. Dalichau and Scheele [31] (p. 119) stated: "After examining sports-specific mechanic demands and taking account of the epidemiological investigations of incidence and prevalence of spinal injuries in weight lifting the results evaluated are to interpret as a functional adaptation of the spinal curvature to the weight lifting-specific straining (sic) profile".

Granhed et al. [48] reported that L3 bone mineral content correlated $(r=0.90)$ with the yearly load (300-5000 tons) of eight elite powerlifters, which indicates a positive influence of the volume of strength training on the development of BMC. Sabo et al. [62] have also presented data of 28 male weightlifters, whose weekly load was 68 tons, with significantly higher BMD values of their lumbar vertebral bodies (L1-L4) (24\% compared to age-matched controls). Tszuzuku et al. [64] have even found a significant correlation $(r=0.74 ; p \leqslant 0.05)$ between 1-RM in the parallel squat and BMD of L2-L4 in ten powerlifters (mean age: 20.7 years). 
It can also be expected that intervertebral discs adapt to years of strength training. Many animal studies lasting 3-15 weeks with dogs $[65,66]$ and rats $[67,68]$ confirm the positive effects of training in different parcours (running, jumping, crawling) [65] and of treadmill training [66-68] on nutrition status [65] and on the structure of intervertebral discs [66-68]. For example, in vivo experiments with rats have shown that caudal nucleus and annulus pulposus positively adapted after two weeks of dynamic compression with $1 \mathrm{MPa}$, which is about three-fold bodyweight [69]. However, most mammalian species possess notochordal cells in the nucleus pulposus at birth, but unlike humans, maintain them throughout much of their adulthood. Notochordal cells have been suggested to be progenitor and/or organizer cells [70]. "They may directly synthesize matrix proteins and eventually differentiate into the mature chondrocytic nucleus cells or they may help to recruit and co-ordinate other mesenchymal cells to synthesize the extracellular matrix" [70] (p. 3). Therefore, findings gathered from animals that maintain notochordal cells well into adult life should be interpreted cautiously [70]. However, Ishihara et al. [71] have reported an increase in proteoglycan metabolism in human vertebral discs (explants) stressed with $2.5 \mathrm{MPa}$, while it decreased if pressure was increased to $7.5 \mathrm{MPa}$. For a comparison, a male $(70 \mathrm{~kg})$ lifting a beer case $(20 \mathrm{~kg})$ from a squatting position already exhibits values of $1.7 \mathrm{MPa}$ (L4/L5) [72]. This is an apparent contradiction to reports of catabolic metabolic reactions of cellular cultures of nucleus pulposus at a pressure of 2.5 MPa [73]. However, several papers have shown that the missing extracellular matrix in single-layered cellular cultures causes them to react differently to mechanic stimuli [70,74], which is why explants [71] are physiologically of higher relevance. In comparison with untrained controls, Tittel [75] diagnosed larger lengthwise and cross-sectional diameters of vertebral bodies of lower thoracic and all lumbar vertebral bodies in strength training athletes with several years of experience. Those economic enlargements had still been detectable even 10 years after the athletic career ended. Moreover, Neumann et al. [76] have reported a positive and linear correlation between BMD of vertebral bodies (ex vivo) and tensile strength $(r=0.84$, $p \leqslant 0.05)$, as well as the stiffness of ligamentum longitudinal anterior $(r=0.78, p \leqslant 0.05)$. In vivo, this would represent an increased passive stability of vertebral segments. In combination with the gain in BMD, enlargement in vertebral body surface area and well-trained trunk musculature, one can state that strength training on a regular basis shows a protective effect.

\subsection{Incidence and Risk of Injuries of the Vertebral Column in Deep Squats}

In weightlifting, athletes perform deep front and back squats, as well as pull and assistance exercises. Both demand high accelerations and loads. International elite weightlifters exercise regularly 10-times per week with 400 and more reps and 70-90 tons of weight in high volume training periods [14]. X-ray images of weightlifters $(n=25$, average age: 31.5 years) do not reveal a higher extent of degenerative changes of the spine compared to track and field athletes $(n=25$; average age: 27.0 years) [29]. By means of magnetic resonance imaging (MRI) scans of T6/7 to L5/S1, Baranto et al. [30] have reported weightlifters $(n=21)$ and ice hockey players $(n=19)$ to have the highest prevalence of degenerative disc abnormalities compared to other professional sportsmen (e.g., wrestlers $(n=13)$ and orienteering $(n=18))$. However, the differences have not been statistically significant even in comparison with untrained, age-matched controls $(n=21)$. A 15-year follow-up diagnosis revealed a deterioration of existing abnormalities in all four groups of athletes that mainly included disc degeneration, which was diagnosed in more than $90 \%$ of the athletes. These abnormalities eased to some degree in $88 \%$ of the athletes, with the highest probabilities for weightlifters and ice-hockey players, but most of them had been ice hockey players [30]. In a recent review about possible adaptations and degenerative changes of intervertebral discs depending on a particular sport, the authors have come to the conclusion that "sports including, swimming, baseball, weightlifting, rowing and equestrian riding are more likely to lead to disc degeneration" [77]. However, their statement about an increased incidence of degenerative effects of weightlifting had only been based on two studies $[78,79]$. One study, with monozygotic twins, determined higher disc degeneration in the T6 to T12 region for the twins who performed weightlifting compared to the twins who 
executed endurance sports. There were no degenerative changes present in the lumbar spine of the weightlifters [79]. However, these weightlifters had already been training in a time when the standing press or "military press" was still an Olympic exercise. Due to missing guidelines [80] and the high injury risk of this exercise [81], it was abandoned in 1972 [80,81]. The same problem exists for the majority of weightlifters in the study by Baranto et al. [30] and Granhed and Morelli [78]. Unfortunately, in their review Belavy et al. [77] did not refer to the strong positive indications of other research groups in this field [31,32].

In contrast, four epidemiological studies, lasting 2.5-6 years, have not revealed any major injuries of the spine in competitive weightlifters [82-85]. Furthermore, MRI scans of lumbar spines of former elite athletes have not shown any statistically-significant differences for vertebral body height (L1/2 to L5/S1) or lumbar flexibility between weightlifters ( $n=29,59.4$ years), long-distance runners $(n=27$, 59.6 years), shooters ( $n=28,61.1$ years) and soccer players ( $n=30,56.6$ years) [32]. According to Baranto et al. [30], the prevalence of disc abnormalities (e.g., reduced intervertebral disc height) of professional weightlifters ( $n=10,42.0$ years) is similar to untrained age-matched controls $(n=10)$. In addition, the incidence of back pain has been reported to be less $(23 \% v s .31 \%)$ in former weightlifters $(n=13)$ compared to the general population $(n=716)$ [78]. According to this, it may be concluded that intervertebral discs in humans are able to adapt to exercise-induced compressive forces in weightlifting training. In the long run, those adaptations lead to an increased stress tolerance.

Walsh et al. [36] reported a statistically significantly $(p \leqslant 0.01)$ increased extension in the lumbar spinal region with growing loads $(40 \%-80 \% 1-\mathrm{RM})$ in 48 strength-trained participants performing the half squat. Therefore, Walsh et al. [36] postulate a performance-oriented strength training in the half squat to increase the risk of injury in the lumbar spine. This assumption is further based on ex vivo measurements in the L4/L5 segments [86]: during axial compression of $2000 \mathrm{~N}$, an extension by $2^{\circ}$ compared to $0^{\circ}$ statistically significantly increased intradiscal pressure within the posterior annulus. The concerns by Walsh et al. [36] are unfounded, as the angle of the hip also changes. This is why in the deep squat at the turning point, the risk of delordosing of the lumbar spine is raised [35]. Video analyses have shown males exhibiting a smaller anterior pelvic tilt and a larger ventral flexion of the lumbar spine during the lowering phase of the parallel squat compared to females $(p \leqslant 0.001)$ [35]. The gender differences could result from larger range of motion in the hip in females [87]. However, participants performed squats with submaximal loads of 0.5 -fold bodyweight. Higher loads should also increase the risk of delordosing in females. Lander et al. [88] analyzed the parallel squat of five strength-training experienced males with $75 \%-80 \%$ 1-RM. Induced fatigue led to increased upper body tilt. Trafimov et al. [89] confirmed that a fatigued quadriceps femoris affected lifting technique with regard to performing a back lift rather than a squat lift. However, an increased upper body tilt raises the risk of ventral flexion of the thoracic and the lumbar spine [33].

To minimize delordosing, it is necessary to start extension before the turning point. This can be achieved with increased activity of the erector spinae, which keeps intervertebral distances constant due to the closing of the apophyseal joints and therefore reduces anterior shear forces on discs [23]. Weightlifters also have to remain in lordosis at movement onset in snatch and clean. Calhoon and Fry [83] reported an incidence of 3.3 injuries per $1000 \mathrm{~h}$ of weightlifting training in 27 Olympic weightlifters in a period of six years. Training interruption of one day or less accounted for $87.3 \%$ of injuries concerning the lower back, while the remaining cases interrupted training for less than one week. Based on a questionnaire for 13-16-year-old weightlifters $(n=1634)$, Hamill [84] reported a prevalence for injury of 0.0017 per $100 \mathrm{~h}$. Therefore, the rate of injury is less than in basketball (0.03), track and field (0.57), American football (0.1) and gymnastics (0.044) [84].

Byrd et al. [82] could not document any kind of injury or training interruption in 11 adolescent weightlifters (three females: $13.7 \pm 1.2$ years; eight males: $12.5 \pm 1.6$ years) in an observational period of 29 months in which they had performed 534 trials in competitions. In a retrospective study (four years) with 1109 weightlifters aged $12-20$ years, who had participated in national and international competitions, no injuries that induced a chirurgic treatment or a hospital stay were reported [85]. 
4.4. Risk of Injuries of the Knee Joint and Vertebral Column Due to the Restriction of the Anterior Knee Displacement in the Squat

If the parallel or the deep squat are performed with the spine remaining as vertical as possible, the anterior movement of the knee exceeds the toes (unrestricted movement). This has been regarded with concern by practitioners, as retropatellar pressure and tibiofemoral shear forces have been expected to increase and cause cartilage damage. Based on a literature review, we have been able to show that this is without any reason [90]. For the restricted movement, it is recommended that the tibia should move anteriorly only to the point where the knee joints and the toes form a vertical line [91]. Fry et al. [91] calculated statistically-significant increases in peak torque of the knee joint at the turning point in seven male subjects performing the back squat (with 1.0-fold bodyweight) without this movement restriction. The average knee angles at the turning point were $66.1^{\circ}$ compared to the restricted condition that was performed to $73.4^{\circ}$. However, based on Figure 1, the restricted condition in the high-bar squat bears the risk of ventral flexion of the spine and cannot be considered as a correct execution of the squat. Lorenzetti et al. [34] confirmed these results for the unrestricted condition and reported statistically significantly higher relative knee joint torque of $25 \%(p<0.05)$ with 0.5 -fold bodyweight. In this case, however, the turning point in the range of motion restricted variation for their 20 subjects had been on average $91^{\circ}$ (= half squat). This was, again, confirmed by that workgroup with more participants $(n=30)$ [33].
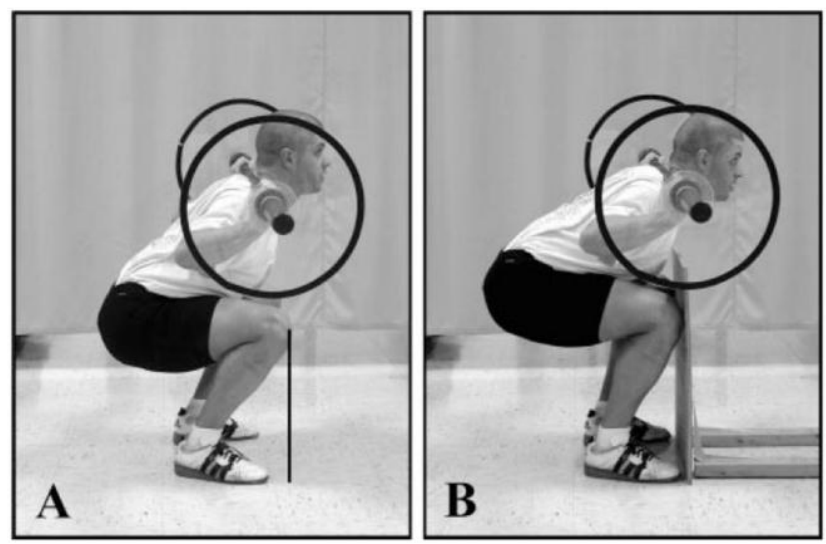

Figure 1. (A) Unrestricted back squat (high bar) where the knees are able to move anteriorly as far as necessary. The line illustrates the amount of anterior displacement of the knees relative to the toes. (B) Restricted back squat (high bar), where a vertical board restricts anterior knee displacement. Adapted from Fry et al. [91], with permission.

If the dependence of squatting depth and load and their influence on the enlargement of the retropatellar articular surface are taken into account, usage of comparably supramaximal weight loads in the half squat lead to higher torques and therefore higher pressure in the tibio- and patello-femoral joints. The greatest retropatellar compressive forces (in N) [92-94] and highest compressive stresses $\left(\mathrm{N} / \mathrm{mm}^{2}\right.$, in $\left.\mathrm{MPa}\right)[93,95]$ are observed at $90^{\circ}$. With increasing flexion of the knee joint in the deep squat, a cranial displacement of facet contact areas with continuous enlargement of the retropatellar articulating surface occurs [93,95-97]. The additional contact between the quadriceps tendon and the intercondylar notch as the tendofemoral support surface ("wrapping effect" [92]) contributes to an improved load distribution and enhanced force transfer [92-95,98]. Both factors (increasing facet contact areas, wrapping effect) reduce retropatellar compressive forces [92-94,98] and stresses [93,95]. Furthermore, the soft tissue contact between the back of the thigh and the calf plays an important role in reducing the tibiofemoral and patellofemoral joint forces beyond $60^{\circ}-40^{\circ}$ of knee extension in the deep squat $[99,100]$, depending on the cross-sectional area of the hamstrings and the calf muscles [101]. Besides lower weights, deep squats benefit from these relief effects that compensate for increases in 
knee-joint torques due to unrestricted forward movement of the knee, provided that the heels stay in contact with the ground. These factors cannot arise when an evasive movement of the trunk is performed owing to the restriction of the forward movement of the knees. The accomplishment of the half squat with supramaximal loads will endanger the knee joint by degenerative changes in the long term [90]. In addition, Lorenzetti et al. [34] reported statistically significantly higher relative torques in the hip joint at the turning point $(14.6 \% ; p<0.05)$, when the half squat was performed under restricted anterior knee movement. Fry et al. [91] even reported 10-fold higher peak torques in the hip joint under this condition. These higher torque values in the hip joint bring additional increases in compressive forces at the sacroiliac joint and, therefore, the lumbar spinal region when performing the half squat with supramaximal loads. The restriction of the forward knee displacement will result in greater forward leaning [91] with the risk of ventral flexion of the thoracic and lumbar spine [33]. This evasive movement induces greater anterior shear forces on intervertebral discs [23] and elicits tensile forces on intervertebral ligaments $[23,102]$. The load combination of high-axial compressive and shear forces in ventral flexion increases the risk of a spinal discus prolapse [42].

The instruction about a restriction of the forward knee displacement is a misinterpretation of the existing literature (for a discussion, see [90]). It is strongly emphasized that this instruction should not be further recommended.

\section{Conclusions}

To achieve the necessary intensities for a hypertrophy-oriented training or even training with maximal contractions in the half or the quarter squat, loads have to be supramaximal compared to the deep or the parallel squat. Physical activity students were able to lift a 2.8-fold load in the quarter squat compared to the deep back squat and even a 3.17-fold load of the deep front squat [17]. After 10 weeks of training intervention, this relation rose significantly to $4.02(p=0.0001)$ and $4.38(p=0.0001)$ [17]. However, participants were in danger of collapsing at their thoracic spine during training and testing. Back extensors had been the limiting factor [17]. The multiplicated axial compressive forces in the L3/L4 vertebral segment could reach 20-fold bodyweight. Strength training-experienced subjects could lift even higher loads: taking values of a powerlifter performing the deep back squat [103] with $250 \mathrm{~kg}$, he could lift $1005 \mathrm{~kg}$ in the quarter squat. This is impossible in practice. A load like this cannot be stabilized by the trunk and the thoracic spine. Therefore, it would be impossible to introduce the necessary intensity to reach further adaptations of the hip and leg extensors.

On the other hand, there are plenty of studies showing no increased risk of injury in the lumbar spinal segment when performing the deep squat in weightlifting [29-31,82-85]. The perennial training structure of athletes focuses on minimal goals of 1.5-2.0-fold bodyweight in the deep squat [18]. This leads to less shear and compressive forces for vertebral segments compared to supramaximal loads necessary in the half and quarter squat. Keiner et al. [104] recommended minimal reference values for the parallel front and back squat for up-and-coming players after 4-5 years of strength training experience with 2.0-fold bodyweight for 16-19-year-old, 1.5-fold bodyweight for 13-15-year-old and 0.7 -fold bodyweight for 11-12-year-old players. Those recommendations have been cited and advocated by others [105-109]. For parallel front and back squats, we, like others [24], recommend relative strength values of 2.0-2.5-fold bodyweight for adult athletes.

Another publication from the same project [110] has been used in the "position statement on youth resistance training: the 2014 international consensus" [111] as proof that periodized strength training using the parallel squat is unproblematic for children and adolescents as long as movement execution is technically correct at all times and loads are enhanced slowly. Preferential bone formation on the periosteal surface [112-114] is facilitated by exercise during growth, especially before puberty. Substantial skeletal benefits may be expected during pre and early puberty ("window of opportunity") and become considerably smaller thereafter [115]. Therefore, early beginning of strength training during pre-puberty is no recommendation for improving health and athletic performance, it is a commandment (see [116]). 
Provided that movement execution is taught by professionals and loads are enhanced according to the adaptive processes in the passive tissue, the parallel and the deep squat lead to structurally significant long-term improvements. Several studies have shown the deep and the parallel squat to induce more strain and therefore lead to better development of muscle cross-sectional area of the lower extremity [117], dynamic maximal strength [17,117], speed-strength capacity in squat jump [117] and countermovement jump [17] compared to the quarter squat. Even for the half squat, it seems questionable if comparable adaptive stimuli can be generated in the long term. Taking into account the increased risk of injury caused by the higher shear and compressive forces in the vertebral column and the knee joint, we come to the conclusion that the half and the quarter squat should not further be recommended.

Acknowledgments: The authors declare that there were no sources of funding. The authors would like to thank Mark Rippetoe for vital comments on the manuscript.

Author Contributions: All authors contributed substantially to the work of this narrative review.

Conflicts of Interest: There are no conflicts of interest.

\section{Abbreviations}

The following abbreviations are used in this manuscript:

$\begin{array}{ll}\text { BMC } & \text { Bone mineral content } \\ \text { BMD } & \text { Bone mineral density } \\ \mathrm{MPa} & \text { Megapascal }\left(\mathrm{N} / \mathrm{mm}^{2}\right) \\ \mathrm{N} & \text { Newton } \\ \mathrm{CSA} & \text { Muscle cross-sectional area } \\ \text { 1-RM } & \text { One repetition maximum } \\ \mathrm{RM} & \text { Repetition maximum }\end{array}$

\section{References}

1. Wretenberg, P.; Feng, Y.; Arborelius, U.P. High- and low-bar squatting techniques during weight-training. Med. Sci. Sports Exerc. 1996, 28, 218-224. [CrossRef] [PubMed]

2. Caterisano, A.; Moss, R.F.; Pellinger, T.K.; Woodruff, K.; Lewis, V.C.; Booth, W.; Khadra, T. The effect of back squat depth on the EMG activity of 4 superficial hip and thigh muscles. J. Strength Cond. Res. 2002, 16, 428-432. [CrossRef] [PubMed]

3. Wilson, G.J. Strength and power in sport. In Applied Anatomy and Biomechanics in Sport, 3rd ed.; Bloomfield, J., Ackland, T.R., Elliott, B.C., Eds.; Blackwell: Berlin, Germany, 1998; pp. 110-208.

4. Cotter, J.A.; Chaudhari, A.M.; Jamison, S.T.; Devor, S.T. Knee joint kinetics in relation to commonly prescribed squat loads and depths. J. Strength Cond. Res. 2013, 27, 1765-1774. [CrossRef] [PubMed]

5. Fry, A.C.; Aro, T.A.; Bauer, J.A.; Kraemer, W.J. A comparison of methods for determining kinematic properties of three barbell squat exercises. J. Hum. Mov. Stud. 1993, 24, 83-95.

6. Wretenberg, P.; Feng, Y.; Lindberg, F.; Arborelius, U.P. Joint moments of force and quadriceps muscle activity during squatting exercise. Scand. J. Med. Sci. Sports 1993, 3, 244-250. [CrossRef]

7. Ratamess, N.A.; Alvar, B.A.; Evetoch, T.K.; Housh, T.J.; Kibler, W.B.; Kraemer, W.J.; Triplett, N.T. American College of Sports Medicine position stand. Progression models in resistance training for healthy adults. Med. Sci. Sports Exerc. 2009, 41, 687-708.

8. Kraemer, W.J.; Ratamess, N.A. Fundamentals of resistance training: Progression and exercise prescription. Med. Sci. Sports Exerc. 2004, 36, 674-688. [CrossRef] [PubMed]

9. Schmidtbleicher, D. Training for power events. In Strength and Power in Sport, 2nd ed.; Komi, P., Ed.; Blackwell Science: Oxford, UK, 1992; pp. 381-395.

10. Schoenfeld, B. The mechanisms of muscle hypertrophy and their application to resistance training. J. Strength Cond. Res. 2010, 24, 2857-2872. [CrossRef] [PubMed]

11. Stone, M.H.; Stone, M.; Sands, W. Principles and Practice of Resistance Training; Human Kinetics: Champaign, IL, USA, 2007. 
12. Wernbom, M.; Augustsson, J.; Thomeé, R. The influence of frequency, intensity, volume and mode of strength training on whole muscle cross-sectional area in humans. Sports Med. 2007, 37, 225-264. [CrossRef] [PubMed]

13. Fry, A.C. The role of resistance exercise intensity on muscle fibre adaptations. Sports Med. 2004, 34, 663-679. [CrossRef] [PubMed]

14. Wirth, K.; Zawieja, M. Experiences from weightlifting for competitive strength training. Part 2: Differences in periodization and designing of strength training in weightlifting and other sports with high demands on speed-strength. Leistungssport 2008, 38, 50-54. (In German)

15. Zatsiorsky, V.M.; Kraemer, W. Science and Practice of Strength Training, 2nd ed.; Human Kinetics: Champaign, IL, USA, 2006.

16. Hoff, J.; Helgerud, J. Maximal strength training enhances running economy and aerobic endurance performance. In Football (Soccer). New Developments in Physical Training Research; Hoff, J., Helgerud, J., Eds.; NTNU: Trondheim, Norway, 2003; pp. 39-55.

17. Hartmann, H.; Wirth, K.; Klusemann, M.; Dalic, J.; Matuschek, C.; Schmidtbleicher, D. Influence of squatting depth on jumping performance. J. Strength Cond. Res. 2012, 26, 3243-3261. [CrossRef] [PubMed]

18. Wirth, K.; Zawieja, M. Experiences from weightlifting for competitive strength training. Part 1: Importance of competition and training exercises of weightlifting for the development of speed-strength. Leistungssport 2008, 38, 10-13. (In German)

19. Cappozzo, A.; Felici, F.; Figura, F.; Gazzani, F. Lumbar spine loading during half-squat exercises. Med. Sci. Sports Exerc. 1985, 17, 613-620. [CrossRef] [PubMed]

20. Kuo, C.-S.; Hu, H.-T.; Huang, K.-Y.; Zhong, Z.-C.; Hseih, M.-L. Biomechanical analysis of the lumbar spine on facet joint and intradiscal pressure-A finite element study. BMC Musculoskelet. Disord. 2010, 11, 1-13. [CrossRef] [PubMed]

21. Bressel, E.; Willardson, J.M.; Thompson, B.; Fontana, F.E. Effect of instruction, surface stability, and load intensity on trunk muscle activity. J. Electromyogr. Kinesiol. 2009, 19, e500-e504. [CrossRef] [PubMed]

22. Nuzzo, J.L.; McCaulley, G.O.; Cormie, P.; Cavill, M.J.; McBride, J.M. Trunk muscle activity during stability ball and free weight exercises. J Strength Cond. Res. 2008, 22, 95-102. [CrossRef] [PubMed]

23. Potvin, J.R.; Norman, R.W.; McGill, S.M. Reduction in anterior shear forces on the $\mathrm{L}_{4} / \mathrm{L}_{5}$ disc by the lumbar musculature. Clin. Biomech. 1991, 6, 88-96. [CrossRef]

24. Dintiman, G.; Ward, B. Sports Speed, 3rd ed.; Human Kinetics: Champaign, IL, USA, 2003.

25. Helgerud, J.; Kemi, O.J.; Hoff, J. Pre-season concurrent strength and endurance development in elite soccer players. In Football (Soccer). New Developments in Physical Training Research; Hoff, J., Helgerud, J., Eds.; NTNU: Trondheim, Norway, 2003; pp. 55-66.

26. Rønnestad, B.R. Comparing the performance-enhancing effects of squats on a vibration platform with conventional squats in recreationally resistance-trained men. J. Strength Cond. Res. 2004, 18, 839-845. [CrossRef] [PubMed]

27. Schoenfeld, B.J. Squatting kinematics and kinetics and their application to exercise performance. J. Strength Cond. Res. 2010, 24, 3497-3506. [CrossRef] [PubMed]

28. Lander, J.E.; Simonton, R.L.; Giacobbe, J.K.F. The effectiveness of weight-belts during the squat exercise. Med. Sci. Sports Exerc. 1990, 22, 117-126. [CrossRef] [PubMed]

29. Aggrawal, N.D.; Kaur, R.; Kumar, S.; Mathur, D.N. A study of changes in the spine in weight lifters and other athletes. Br. J. Sports Med. 1979, 13, 58-61. [CrossRef] [PubMed]

30. Baranto, A.; Hellström, M.; Cederlund, C.-G.; Nyman, R.; Swärd, L. Back pain and MRI changes in the thoraco-lumbar spine of top athletes in four different sports: A 15-year follow-up study. Knee Surg. Sports Traumatol. Arthrosc. 2009, 17, 1125-1134. [CrossRef] [PubMed]

31. Dalichau, S.; Scheele, K. Are there any influences of sports mechanic demands in weightlifting on the thoracolumbar curvature? Schweiz. Z. Sportmed. Sporttraumatol. 2001, 49, 119-123. (In German)

32. Räty, H.P.; Battié, M.C.; Videman, T.; Sarna, S. Lumbar mobility in former elite male weightlifters, soccer players, long-distance runners and shooters. Clin. Biomech. 1997, 12, 325-330. [CrossRef]

33. List, R.; Gulay, T.; Stoop, M.; Lorenzetti, S. Kinematics of the trunk and the lower extremities during restricted and unrestricted squats. J. Strength Cond. Res. 2013, 27, 1529-1538. [CrossRef] [PubMed]

34. Lorenzetti, S.; Gülay, T.; Stoop, M.; List, R.; Gerber, H.; Schellenberg, F.; Stüssi, E. Comparison of the angles and corresponding moments in the knee and hip during restricted and unrestricted squats. J. Strength Cond. Res. 2012, 28, 2829-2836. [CrossRef] [PubMed] 
35. McKean, M.R.; Dunn, P.K.; Burkett, B.J. The lumbar and sacrum movement pattern during the back squat exercise. J. Strength Cond. Res. 2010, 24, 2731-2741. [CrossRef] [PubMed]

36. Walsh, J.C.; Quinlan, J.F.; Stapleton, R.; FitzPatrick, D.P.; McCormack, D. Three-dimensional motion analysis of the lumbar spine during "free squat" weight lift training. Am. J. Sports Med. 2007, 35, 927-932. [CrossRef] [PubMed]

37. Brinckmann, P.; Biggemann, M.; Hilweg, D. Prediction of the compressive strength of human lumbar vertebrae. Clin. Biomech. Suppl. 1989, 2, S1-S27.

38. Hutton, W.C.; Adams, M.A. Can the lumbar spine be crushed in heavy lifting? Spine 1982, 7, 586-590. [CrossRef] [PubMed]

39. Hutton, W.C.; Cyron, B.M.; Stott, J.R.R. The compressive strength of lumbar vertebrae. J. Anat. 1979, 129, 753-758. [PubMed]

40. Jäger, M.; Luttmann, A. Compressive strength of lumbar elements related to age, gender, and other influencing factors. In Electromyographical Kinesiology; Anderson, P.A., Hobart, D.J., Danoff, J.V., Eds.; Excerpta Medica: Amsterdam, The Netherlands; New York, NY, USA; Oxford, UK, 1991; pp. 291-294.

41. Porter, R.W.; Adams, M.A.; Hutton, W.C. Physical activity and the strength of the lumbar spine. Spine 1989, 14, 201-203. [CrossRef] [PubMed]

42. Adams, M.A.; Hutton, W.C. Gradual disc prolapse. Spine 1985, 10, 524-531. [CrossRef] [PubMed]

43. Krismer, M.; Haid, Ch.; Rabl, W. The contribution of anulus fibers to torque resistance. Spine 1996, 21, 2551-2557. [CrossRef] [PubMed]

44. Hickey, D.S.; Hukins, D.L. Relation between the structure of the annulus fibrosus and the function and failure of the intervertebral disc. Spine 1980, 5, 106-116. [CrossRef] [PubMed]

45. Schmidt, H.; Kettler, A.; Heuer, F.; Simon, U.; Claes, L.; Wilke, H.-J. Intradiscal pressure, shear strain, and fiber strain in the intervertebral disc under combined loading. Spine 2007, 32, 748-755. [CrossRef] [PubMed]

46. Bader, D.L.; Bouten, C. Biomechanics of soft tissues. In Clinical Biomechanics; Dvir, Z., Ed.; Churchill Livingstone: New York, NY, USA; Edinburgh, Scotland; London, UK; Philadelphia, PA, USA, 2000; pp. $35-64$.

47. Cormie, P.; McBride, J.M.; McCaulley, G.O. Power-time, force-time, and velocity-time curve analysis of the countermovement jump: Impact of training. J. Strength Cond. Res. 2009, 23, 177-186. [CrossRef] [PubMed]

48. Granhed, H.; Jonson, R.; Hansson, T. The loads on the lumbar spine during extreme weight lifting. Spine 1987, 12, 146-149. [CrossRef] [PubMed]

49. Jäger, M.; Luttmann, A. Biomechanical analysis and assessment of lumbar stress during load lifting using a dynamic 19-segment human model. Ergonomics 1989, 32, 93-112. [CrossRef] [PubMed]

50. Gilsanz, V.; Boechat, M.I.; Gilsanz, R.; Loro, M.L.; Roe, T.F.; Goodman, W.G. Gender differences in vertebral sizes in adults: Biomechanical implications. Radiology 1994, 190, 678-682. [CrossRef] [PubMed]

51. Ebbesen, E.N.; Thomsen, J.S.; Beck-Nielsen, H.; Nepper-Rasmussen, H.J.; Mosekilde, L. Age- and gender-related differences in vertebral bone mass, density, and strength. J. Bone Miner. Res. 1999, 14, 1394-1403. [CrossRef] [PubMed]

52. Ebbesen, E.N.; Thomsen, J.S.; Beck-Nielsen, H.; Nepper-Rasmussen, H.J.; Mosekilde, L. Lumbar vertebral body compressive strength evaluated by dual-energy X-ray absorptiometry, quantitative computed tomography, and ashing. Bone 1999, 25, 713-724. [CrossRef]

53. Conroy, B.P.; Kraemer, W.J.; Maresh, C.M.; Fleck, S.J.; Stone, M.H.; Fry, A.C.; Miller, P.D.; Dalsky, G.P. Bone mineral density in elite junior Olympic weightlifters. Med. Sci. Sports Exerc. 1993, 25, 1103-1109. [CrossRef] [PubMed]

54. Fleck, S.J.; Kraemer, W.J. Designing Resistance Training Programs, 3rd ed.; Human Kinetics: Champaign, IL, USA, 2004.

55. Lang, T.F.; Saeed, I.H.; Streeper, T.; Carballido-Gamio, J.; Harnish, R.J.; Frassetto, L.A.; Lee, S.M.; Sibonga, J.D.; Keyak, J.H.; Spiering, B.A.; et al. Spatial heterogeneity in the response of the proximal femur to two lower-body resistance exercise regimens. J. Bone Miner. Res. 2014, 29, 1337-1345. [CrossRef] [PubMed]

56. Loehr, J.A.; Lee, S.M.; English, K.L.; Sibonga, J.; Smith, S.M.; Spiering, B.A.; Hagan, R.D. Musculoskeletal adaptations to training with the advanced resistive exercise device. Med. Sci. Sports Exerc. 2011, 43, 146-156. [CrossRef] [PubMed]

57. Almstedt, H.C.; Canepa, J.A.; Ramirez, D.A.; Shoepe, T.C. Changes in bone mineral density in response to 24 weeks of resistance training in college-age men and women. J. Strength Cond. Res. 2011, 25, 1098-1103. [CrossRef] [PubMed] 
58. Dalsky, G.P. Exercise: Its effect on bone mineral content. Clin. Obstet. Gynecol. 1987, 30, 820-832. [CrossRef] [PubMed]

59. Chilibeck, P.D.; Calder, A.; Sale, D.G.; Webber, C.E. Twenty weeks of weight training increases lean tissue mass but not bone mineral mass or density in healthy, active young women. Can. J. Physiol. Pharmacol. 1996, 74, 1180-1185. [CrossRef] [PubMed]

60. Dinç, H.; Savci, G.; Demirci, A.; Sadikoğlu, M.Y.; Tuncel, E.; Yavuz, H. Quantitative computed tomography for measuring bone mineral density in athletes. Calcif. Tissue Int. 1996, 58, 398-401. [CrossRef] [PubMed]

61. Karlsson, M.K.; Johnell, O.; Obrant, K.J. Bone mineral density in weight lifters. Calcif. Tissue Int. 1993, 52, 212-215. [CrossRef] [PubMed]

62. Sabo, D.; Benrd, L.; Pfeil, J.; Reiter, A. Bone quality in the lumbar spine in high-performance athletes. Eur. Spine J. 1996, 5, 258-263. [CrossRef] [PubMed]

63. Heinonen, A.; Oja, P.; Kannus, P.; Sievänen, H.; Mänttäri, A.; Vuori, I. Bone mineral density of female athletes in different sports. Bone Miner. 1993, 23, 1-14. [CrossRef]

64. Tszuzuku, S.; Ikegami, Y.; Yabe, K. Effects of high-intensity resistance training on bone mineral density in young male powerlifters. Calcif. Tissue Int. 1998, 63, 283-286. [CrossRef]

65. Holm, S.; Nachemson, A. Variations in the nutrition of the canine intervertebral disc induced by motion. Spine 1983, 8, 866-874. [CrossRef] [PubMed]

66. Säämänen, A.-M.; Puustjärvi, K.; Ilves, K.; Lammi, M.; Kiviranta, I.; Jurvelin, J.; Helminen, H.J.; Tammi, M. Effect of running exercise on proteoglycans and collagen content in the intervertebral disc of young dogs. Intern. J. Sports Med. 1993, 14, 48-51. [CrossRef] [PubMed]

67. Brisby, H.; Wei, A.Q.; Molloy, T.; Chung, S.A.; Murrell, G.A.; Diwan, A.D. The effect of running exercise on intervertebral disc extracellular matrix production in a rat model. Spine 2010, 35, 1429-1436. [CrossRef] [PubMed]

68. Sasaki, N.; Henriksson, H.B.; Runesson, E.; Larsson, K.; Sekiguchi, M.; Kikuchi, S.-I.; Konno, S.-I.; Rydevik, B.; Brisby, H. Physical exercise affects cell proliferation in lumbar intervertebral disc regions in rats. Spine 2012, 37, 1440-1447. [CrossRef] [PubMed]

69. Wuertz, K.; Godburn, K.; MacLean, J.J.; Barbir, A.; Donnelly, J.S.; Roughley, P.J.; Alini, M.; Iatridis, J.C. In vivo remodeling of intervertebral discs in response to short- and long-term dynamic compression. J. Orthop. Res. 2009, 27, 1235-1242. [CrossRef] [PubMed]

70. Alini, M.; Eisenstein, S.M.; Ito, K.; Little, Ch.; Kettler, A.A.; Masuda, K.; Melrose, J.; Ralphs, J.; Stokes, I.; Wilke, H.J. Are animal models useful for studying human disc disorders/degeneration? Eur. Spine J. 2008, 17, 2-19. [CrossRef] [PubMed]

71. Ishihara, H.; McNally, D.S.; Urban, J.P.G.; Hall, A.C. Effects of hydrostatic pressure on matrix synthesis in different regions of the intervertebral disk. J. Appl. Physiol. 1996, 80, 839-846. [PubMed]

72. Wilke, H.J.; Neef, P.; Caimi, M.; Hoogland, T.; Claes, E. New in vivo measurements of pressures in the intervertebral disc in daily life. Spine 2009, 24, 755-762. [CrossRef]

73. Neidlinger-Wilke, C.; Würtz, K.; Urban, J.P.G.; Börm, W.; Arand, M.; Ignatius, A.; Wilke, H.-J.; Claes, L.E. Regulation of gene expression in intervertebral disc cells by low and high hydrostatic pressure. Eur. Spine J. 2006, 15 (Suppl. S3), S372-S378. [CrossRef] [PubMed]

74. Parkkinen, J.J.; Lammi, M.J.; Helminen, H.J.; Tammi, M. Local stimulation of proteoglycan synthesis in articular cartilage explants by dynamic compression in vitro. J. Orthop. Res. 1992, 10, 610-620. [CrossRef] [PubMed]

75. Tittel, K. Descriptive and functional anatomy of men; Urban and Fischer: Jena, Germany, 1994. (In German)

76. Neumann, P.; Keller, T.; Ekström, L.; Hult, E.; Hansson, T. Structural properties of the anterior longitudinal ligament. Correlation with lumbar bone mineral content. Spine 1993, 18, 637-645. [CrossRef] [PubMed]

77. Belavy, D.L.; Albracht, K.; Bruggemann, G.-P.; Vergroesen, P.-P.A.; van Dieen, J.H. Can exercise positively influence the intervertebral disc? Sports Med. 2016, 46, 473-485. [CrossRef] [PubMed]

78. Granhed, H.; Morelli, B. Low back pain among retired wrestlers and heavyweight lifters. Am. J. Sports Med. 1988, 16, 530-533. [CrossRef] [PubMed]

79. Videman, T.; Battié, M.C.; Gibbons, L.E.; Manninen, H.; Gill, K.; Fisher, L.D.; Koskenvuo, M. Lifetime exercise and disk degeneration: An MRI study of monozygotic twins. Med. Sci. Sports Exerc. 1997, 29, 1350-1356. [CrossRef] [PubMed] 
80. Fair, J.D. The tragic history of the military press in Olympic and world championship competition, 1928-1972. J. Sport Hist. 2001, 28, 345-374.

81. Stone, M.H.; Fry, A.C.; Ritchie, M.; Stoessel-Ross, L.; Marsit, J.L. Injury potential and safety aspects of weightlifting movements. Strength Cond. J. 1994, 16, 15-21. [CrossRef]

82. Byrd, R.; Pierce, K.; Rielly, L.; Brady, J. Young weightlifters' performance across time. Sports Biomech. 2003, 2, 133-140. [CrossRef] [PubMed]

83. Calhoon, G.; Fry, A.C. Injury rates and profiles of elite competitive weightlifters. J. Athl. Train. 1999, 34, 232-238. [PubMed]

84. Hamill, B.P. Relative safety of weightlifting and weight training. J. Strength Cond. Res. 1994, 8, 53-57. [CrossRef]

85. Lavallee, M.E.; Balam, T. An overview of strength training injuries: Acute and chronic. Curr. Sports Med. Rep. 2010, 9, 307-313. [CrossRef] [PubMed]

86. Adams, M.A.; May, S.; Freeman, B.J.C.; Morrison, H.P.; Dolan, P. Effects of backward bending on lumbar intervertebral discs. Relevance to physical therapy treatments for low back pain. Spine 2000, 25, 431-437. [CrossRef] [PubMed]

87. Cipriani, D.J.; Terry, M.E.; Haines, M.A.; Tibibnia, A.P.; Lyssanova, O. Effect of stretch frequency and sex on the rate of gain and rate of loss in muscle flexibility during a hamstring-stretching program: A randomized single-blind longitudinal study. J. Strength Cond. Res. 2012, 26, 2119-2129. [CrossRef] [PubMed]

88. Lander, J.E.; Hundley, J.R.; Simonton, R.L. The effectiveness of weight-belts during multiple repetitions of the squat exercise. Med. Sci. Sports Exerc. 1992, 24, 603-609. [CrossRef] [PubMed]

89. Trafimow, J.H.; Schipplein, O.D.; Novak, G.J.; Andersson, G.P. The effects of quadriceps fatigue on the technique in lifting. Spine 1993, 18, 364-367. [CrossRef] [PubMed]

90. Hartmann, H.; Wirth, K.; Klusemann, M. Analysis of the load on the knee joint and vertebral column with changes in squatting depth and weight load. Sports Med. 2013, 43, 993-1008. [CrossRef] [PubMed]

91. Fry, A.C.; Smith, Ch.; Schilling, B.K. Effect of knee position on hip and knee torques during the barbell squat. J. Strength Cond. Res. 2003, 17, 629-633. [CrossRef] [PubMed]

92. Bandi, W. The retropatellar knee joint-diseases. Pathomechanics and pathologic anatomy, clinic and therapy; Verlag Hans Huber, Bern, Stuttgart: Wien, Austria, 1977. (In German)

93. Huberti, H.H.; Hayes, W.C. Patellofemoral contact pressures. The influence of Q-angle and tendofemoral contact. J. Bone Jt. Surg. 1984, 66, 715-724.

94. Nisell, R.; Ekholm, J. Patellar forces during knee extension. Scand. J. Rehabil. Med. 1985, 17, 63-74. [PubMed]

95. Hehne, H.J. Biomechanics of the patellofemoral joint and its clinical relevance. Clin. Orthop. Relat. Res. 1990, 258, 73-85. [CrossRef] [PubMed]

96. Eckstein, F.; Lemberger, B.; Gratzke, C.; Hudelmaier, M.; Glaser, C.; Englmeier, K.-H.; Reiser, M. In vivo cartilage deformation after different types of activity and its dependence on physical training status. Ann. Rheum. Dis. 2005, 64, 291-295. [CrossRef] [PubMed]

97. Hille, E.; Schulitz, K.-P. Determination of contact surfaces of the femoropatellar joint with reference to the localization of chondromalacia. Z. Orthop. Ihre Grenzgeb. 1984, 122, 40-47. (In German) [CrossRef] [PubMed]

98. Ahmed, A.M.; Burke, D.L.; Yu, A. In-vitro measurement of static pressure distribution in synovial joints-Part II: Retropatellar surface. J. Biomech. Eng. 1983, 105, 226-236. [PubMed]

99. Glitsch, U.; Lundershausen, N.; Knieps, D.; Johannknecht, A.; Ellegast, R. Biomechanical analysis of knee joint stress for activities in squatting and kneeling. In 49th Annual Congress of the German Society for Occupational and Environmental Medicine e.V., 11-14 March 2009; DGAUM Verlag: Aachen, Germany, 2009; pp. 391-394. (In German)

100. Zelle, J.; Barink, M.; de Waal Malefijt, M.; Verdonschot, N. Thigh-calf contact: Does it affect the loading of the knee in the high-flexion range? J. Biomech. 2009, 42, 587-593. [CrossRef] [PubMed]

101. Collins, J.J. Antagonistic-synergistic muscle action at the knee during competitive weightlifting. Med. Biol. Eng. Comput. 1994, 32, 168-174. [CrossRef] [PubMed]

102. McGill, S.M. The biomechanics of low back pain injury: Implications on current practice in industry and the clinic. J. Biomech. 1997, 30, 465-475. [CrossRef]

103. Nisell, R.; Ekholm, J. Joint load during the parallel squat in powerlifting and force analysis of in vivo bilateral quadriceps tendon rupture. Scand. J. Sports Sci. 1986, 8, 63-70. 
104. Keiner, M.; Sander, A.; Wirth, K.; Caruso, O.; Immesberger, P.; Zawieja, M. Strength performance in youth: Trainability of adolescents and children in the back and front squats. J. Strength Cond. Res. 2013, 27, 357-362. [CrossRef] [PubMed]

105. Faigenbaum, A.D.; Lloyd, R.S.; MacDonald, J.; Myer, G.D. Citius, Altius, Fortius: Beneficial effects of resistance training for young athletes. Br. J. Sports Med. 2016, 50, 3-7. [CrossRef] [PubMed]

106. Comfort, P.; Stewart, A.; Bloom, L.; Clarkson, B. Relationships between strength, sprint, and jump performance in well-trained youth soccer players. J. Strength Cond. Res. 2014, 28, 173-177. [CrossRef] [PubMed]

107. Haff, G.G.; Nimphius, S. Training principles for power. Strength Cond. J. 2012, 34, 2-12. [CrossRef]

108. Kerr, A. Strength and Conditioning in children and adolescent sport. In Sports Injuries in Children and Adolescents: An Essential Guide; Solomon, A., Ed.; Xlibris Corporation: Bloomington, IN, USA, 2013; pp. 355-366.

109. Lloyd, R.S.; Faigenbaum, A.D.; Myer, G.D.; Stone, M.H.; Oliver, J.L.; Jeffreys, I.; Moody, J.; Brewer, C.; Pierce, K. UKSCA position statement: Youth resistance training. UK Strength Cond. Assoc. 2012, 26, 26-39.

110. Sander, A.; Keiner, M.; Wirth, K.; Schmidtbleicher, D. Influence of a 2-year strength training programme on power performance in elite youth soccer players. Eur. J. Sport Sci. 2012, 13, 1-7. [CrossRef] [PubMed]

111. Lloyd, R.S.; Faigenbaum, A.D.; Stone, M.H.; Oliver, J.L.; Jeffreys, I.; Moody, J.A.; Brewer, C.; Pierce, K.C.; McCambridge, T.M.; Howard, R.; et al. Position statement on youth resistance training: The 2014 International Consensus. Br. J. Sports Med. 2014, 48, 498-505. [CrossRef] [PubMed]

112. Bass, S.I.; Saxon, L.; Daly, R.M.; Turner, C.H.; Robling, A.G.; Seeman, E.; Stuckey, S. The effect of mechanical loading on the size and shape of bone in pre-, peri-, and postpubertal girls: A study in tennis players. J. Bone Miner. Res. 2002, 17, 2274-2280. [CrossRef] [PubMed]

113. Kontulainen, S.; Sievänen, H.; Kannus, P.; Pasanen, M.; Vuori, I. Effect of long-term impact-loading on mass, size, and estimated strength of humerus and radius of female racquet-sports players: A peripheral quantitative computed tomography study between young and old starters and controls. J. Bone Miner. Res. 2003, 18, 352-359. [CrossRef] [PubMed]

114. Warden, S.J.; Fuchs, R.K. Exercise and bone health: Optimising bone structure during growth is key, but all is not vain during ageing. Br. J. Sports Med. 2009, 43, 885-887. [CrossRef] [PubMed]

115. Gunter, K.B.; Almstedt, H.C.; Janz, K.F. Physical activity in childhood may be the key to optimizing lifespan skeletal health. Exerc. Sport Sci. Rev. 2012, 40, 13-21. [CrossRef] [PubMed]

116. Keiner, M.; Sander, A.; Wirth, K.; Schmidtbleicher, D. The impact of 2 years of additional athletic training on the jump performance of young athletes. Sci. Sports 2013, 29, e39-e46. [CrossRef]

117. Bloomquist, K.; Langberg, H.; Karlsen, S.; Madsgaard, S.; Boesen, M.; Raastad, T. Effect of range of motion in heavy load squatting on muscle and tendon adaptations. Eur. J. Appl. Physiol. 2013, 113, 2133-2142. [CrossRef] [PubMed]

(C) 2016 by the authors; licensee MDPI, Basel, Switzerland. This article is an open access article distributed under the terms and conditions of the Creative Commons Attribution (CC-BY) license (http://creativecommons.org/licenses/by/4.0/). 